\title{
Expression of Concern to: A protocol for a cluster-randomized controlled trial testing an empowerment intervention to prevent sexual assault in upper primary school adolescents in the informal settlements of Nairobi, Kenya
}

\author{
Clea Sarnquist ${ }^{1 *}$, Jennifer Lee Kang ${ }^{1}$, Mary Amuyunzu-Nyamongo ${ }^{2}$, Gabriel Oguda $^{2}$, Dorothy Otieno ${ }^{2}$, \\ Benjamin Mboya $^{3}$, Nancy Omondi ${ }^{3}$, Duncan Kipkirui ${ }^{3}$ and Michael Baiocchi
}

Expression of Concern to: BMC Public Health 19, 834 (2019)

http://orcid.org/10.1186/s12889-019-7154-x

The Editor is issuing an editorial expression of concern to alert readers that after publication, concerns were raised regarding this article [1]. The article presents the original study protocol and states that 'The surveys were given in small groups of two to four girls with one interviewer', which is what was originally planned. However, after publication it has come to light that in the actual study this interviewer to participant ratio was much higher, which is not reflected in the article, even though it was published after the conclusion of the study. Post publication peer review concluded that the higher ratio could affect the results, in that it may have caused underreporting of sexual assault incidents. The actual ratio is under dispute among the authors. Authors Clea Sarnquist, Jennifer Lee Kang, Mary AmuyunzuNyamongo, Gabriel Oguda and Michael Baiocchi disagree with this Expression of Concern. Authors Benjamin Mboya, Nancy Omondi and Duncan Kipkirui agree with this Expression of Concern. Author Dorothy

*Correspondence: cleas@stanford.edu

${ }^{1}$ Stanford University School of Medicine, Stanford, CA, USA

Full list of author information is available at the end of the article
Otieno has not responded to correspondence regarding this Expression of Concern.

\section{Author details \\ ${ }^{1}$ Stanford University School of Medicine, Stanford, CA, USA. ${ }^{2}$ African Institute for Health and Development, Nairobi, Kenya. ${ }^{3}$ Ujamaa-Africa, Nairobi, Kenya. \\ Published online: 27 January 2021 \\ Reference \\ 1. Sarnquist, et al. A protocol for a cluster-randomized controlled trial testing an empowerment intervention to prevent sexual assault in upper primary school adolescents in the informal settlements of Nairobi, Kenya. BMC Public Health. 2019;19:834. https://doi.org/10.1186/s12889-019-7154-X.}

\section{Publisher's Note}

Springer Nature remains neutral with regard to jurisdictional claims in published maps and institutional affiliations.
Ready to submit your research? Choose BMC and benefit from:
- fast, convenient online submission
- thorough peer review by experienced researchers in your field
- rapid publication on acceptance
- support for research data, including large and complex data types
- gold Open Access which fosters wider collaboration and increased citations
- maximum visibility for your research: over 100M website views per year
At BMC, research is always in progress.
Learn more biomedcentral.com/submissions 